\title{
The Importance of eWOM Elements on Online Repurchase Intention: Roles of Trust and Perceived Usefulness
}

\author{
Raden Bernard Eka Hutomo Putra Maduretno ${ }^{\mathrm{a}, *}$, \& Sheellyana Junaedi ${ }^{a}$ \\ ${ }^{a}$ Fakultas Bisnis dan Ekonomika, Universitas Atma Jaya Yogyakarta, Indonesia
}

\begin{abstract}
The purpose of this research is to determine the effect of online review elements, including electronic Word of Mouth (eWOM) quantity, credibility, and quality, on customer's online repurchase intention through the mediating roles of online seller trust and perceived usefulness of the website. A partial least square (PLS) based structural equation modeling (SEM) was chosen to evaluate the measurement of research constructs and test the research hypotheses. This research uses data collected through online questionnaires in Yogyakarta, Indonesia. The respondents' criterion was college students who had read online recommendations before making purchases on Bukalapak.com, an e-commerce platform in Indonesia. The results suggest that the credibility and quality of eWOM have a positive direct effect on consumers' repurchase intention, while the eWOM quantity has a negative influence on repurchase intentions. The eWOM credibility and quality indirectly influence repurchase intentions through trust in the online vendor. The perceived usefulness of the website only mediates the influence of eWOM quality on online repurchase intention. Limitations and further research were also discussed.
\end{abstract}

Keywords: credibility; e-commerce; eWOM; information overload; quality information; repurchase intention

JEL Classification: M31

\footnotetext{
${ }^{*}$ Corresponding Address: Fakultas Bisnis dan Ekonomika, Universitas Atma Jaya Yogyakarta, Jl. Babarsari No. 43, Janti, Caturtunggal, Kec. Depok, Kabupaten Sleman, Daerah Istimewa Yogyakarta 55281, Indonesia. Telp: (0274) 487711 Ext: 3132 Fax: (0274) 4852274. E-mail: bernardeka20@gmail.com.
} 


\section{Introduction}

The rate of e-commerce usage continues to record extraordinary jumps from year to year. Such rapid increase in e-commerce consumer base had been triggered by the various product offerings, ease of transaction, and an extensive logistics network (Hidayanto et al., 2017). This phenomenon contributes to the rapid development of e-commerce in Southeast Asia, especially Indonesia. According to Databoks Data, Indonesia has been named the fastest-growing e-commerce market, with a 78\% growth rate in 2018 (Widowati, 2019). Those e-commerce usage rates indicate that the future of Indonesia's e-commerce looks very promising.

Given such favorable conditions, more and more companies have attempted to take advantage of the growing e-commerce market by improving the service across all channels. Many customers have always wanted to obtain information before making purchases; therefore, many e-marketplaces are currently enhancing virtual spaces on their websites to support those activities-Bukalapak.com, named the third biggest e-commerce in Indonesia. As of September 2018, more than 84 million Indonesian users visiting Bukalapak.com every month (Iprice Insights, 2018). Virtual space provided by Bukalapak.com have made it easier for customers to read reviews, opinions, evaluations, and ratings related to the product. Bukalapak customers can also see various online reviews categorized by the most up-to-date timeline to positive and negative reviews.

Several customers possess natural habits when shopping online; this behavior relies on viewing online reviews before making a purchase decision and has already been recognized in marketing studies. In Indonesia, around 70 percent of buyers trust other customer reviews. Those buyers even trust other customer reviews 12 times more than product descriptions from the seller (Tirto.id, 2016). eWOM communication uses online reviews as the primary reference to analyze customer behavior toward online shopping (Bataineh, 2015; Chong et al., 2018; Matute et al., 2016). The communication refers to the process of consumer participation to share opinions about some products they buy online (Peng et al., 2016).

The study focuses on analyzing the impact of eWOM elements on the consumer's intention to repurchase. Consumers perceive information in online reviews based on quantity, credibility, and quality aspect (Bataineh, 2015; Chong et al., 2018; Matute et al., 2016). Some other studies also consider trust and perceived usefulness as being essential variables that can intervene in consumer behavior while engaged online shopping (Chong et al., 2018; Matute et al., 2016; Yoo \& Ross, 2014). Therefore, this research contributes to extant literature by analyzing the three principal eWOM elements on online reviews that influence customer repurchase decisions. This study also aims to explore whether trust in online vendors and the website's perceived usefulness can also predict customer's responses. An deeper understanding on this issue will help understand the repurchase behavior of online consumers. 


\subsection{Effect of eWOM Elements}

eWOM is defined as the process of consumer participation when sharing opinions about their experiences using products and services online. Marketing literature has considered several elements of eWOM, such as quantity, credibility, and quality (Bataineh, 2015; Matute et al., 2016). Those studies have explored all three of these items simultaneously and developed an integrative framework to explain online reviews' impact on consumers' behavior. Previous studies claim that the different elements of eWOM communications can affect customers' evaluations when shopping online.

When shopping online, most consumers need references to reduce risk. A large amount of information can be a reference to assess how popular and valuable a product is to consumers (Teng et al., 2014). The information quantity relates to the number of online reviews that have been posted to express consumer experience with the use of a product. Consumers who post their reviews about using a product will help other consumers make purchasing decisions (Bataineh, 2015; Matute et al., 2016). Formally, we propose the alternative hypothesis (Ha) as follows:

H1: eWOM quantity (EQUAN) has a positive direct effect that influences online repurchase intention (RI).

Online reviews classified by users as essential factors to make repurchase usually will have detailed information that makes it long. However, long reviews are not always good reviews (Filieri et al., 2019; Huang et al., 2015). Credibility plays an essential role in e-commerce. Consumers will intend to revisit the online store if they can obtain reviews that have credible aspects (Matute et al., 2016; Peng et al., 2016). Formally, we propose the alternative hypothesis (Ha) as follows:

H2: eWOM credibility (ECRED) has a positive direct effect that influences online repurchase intention.

The quality of information can be measured by looking at the relevance, timeliness, accuracy, completeness of a review (Matute et al., 2016). Consumers' behavior when shopping online can be affected by the quality of information by seeking, evaluating, and determining which information is most important. Consumers are faced with various choices and purchasing decisions that are built based on specific needs. These reviews must provide up-to-date information, meet consumer needs, be useful, reliable, and easily understood to meet those needs (Bataineh, 2015; Matute et al., 2016). Formally, we propose the alternative hypothesis (Ha) as follows:

H3: eWOM quality (EQUAL) has a positive direct effect that influences online repurchase intention. 


\subsection{Vendor Trust As A Mediating Variable}

A massive amount of online reviews engenders impact on consumer attitudes as well. This aspect could affect the consumer's perception of online vendors. For example, the higher number of consumers who post online reviews will translate into weaker perceived risk of conducting transactions, thus increasing the consumers' perceived trust level (Hidayanto et al., 2017; Teng et al., 2014;). Formally, we propose the alternative hypothesis (Ha) as follows:

H4: eWOM quantity influences online repurchase intention through vendor trust.

Every level of trustworthiness of an online review will come down if consumers perceive that the seller displays incomplete or biased information. These sellers' activities can affect consumers' negative attitudes toward online vendors (Matute et al., 2016; Park et al., 2011). Building customer trust is one of the ordinary essential circumstances influencing consumers' choices before making a purchase. This aspect could affect online vendors' reputation that plays a critical role in a customer's purchasing decisions (Yang et al., 2019). Formally, we propose the alternative hypothesis (Ha) as follows:

H5: eWOM credibility influences online repurchase intention through vendor trust.

Online vendors who can manage their display into the latest, consistent, and relevant information will be viewed positively by consumers. The level of consumer confidence in online vendors will be reviewed through the existence of the most recent, perfect, consistent, and detailed information (Chen \& Chen, 2019; Matute et al., 2016). Thus, online vendors' capability and willingness to display data in quality online reviews will influence consumers to revisit online stores and make purchases. Formally, we propose the alternative hypothesis (Ha) as follows:

H6: eWOM quality influences online repurchase intention through vendor trust.

\subsection{Perceived Usefulness (PU) of the Website As A Mediating Variable}

Perceived usefulness leads to the stage when customers think that information systems will help or further augment their performance. Consumers will tend to choose to revisit online stores to make purchases if they perceive the online stores to be useful (Chong et al., 2018). Online stores presenting various forms of reviews in large numbers can help consumers observe the product to be purchased. Higher number of reviews that consumers perceive will directly translate into higher benefits and perceived usefulness of the website (Yoo \& Ross, 2014). Those essential factors can compel consumers to revisit the online stores to repeat their purchases (Matute et al., 2016). Formally, we propose the alternative hypothesis (Ha) as follows: 
H7: eWOM quantity influences online repurchase intention through the perceived usefulness of the website.

Online recommendations are viewed as more actual, original, and helpful compared to the information put forth by online sellers. As a result, consumers will only feel the benefits of such online information should the online reviews posted on online stores were structured (Bataineh, 2015). Online reviews can also affect the consumer buying decision processes and their attitude toward the website if online reviews are perceived as trustworthy and useful (Matute et al., 2016; Yeap et al., 2014). As a result, customers will be more willing of returning to the online store to make further purchases. Formally, we propose the alternative hypothesis (Ha) as follows:

H8: eWOM credibility influences online repurchase intention through the perceived usefulness of the website.

If the website (online store) can support the vendor by displaying quality information, consumers will feel that online vendors have worked to keep the information accurate and relevant (Xu \& Yao, 2015; Zheng et al., 2013). When consumers consider online reviews to be valid for their needs, consumers will believe in the usefulness of the website system's message (Chen et al., 2016). Formally, we propose the alternative hypothesis (Ha) as follows:

H9: eWOM quality influences online repurchase intention through the perceived usefulness of the website.

\subsection{Research Framework}

The research framework is modified from the study of Matute et al. (2016). The research framework, as shown in Figure 1.

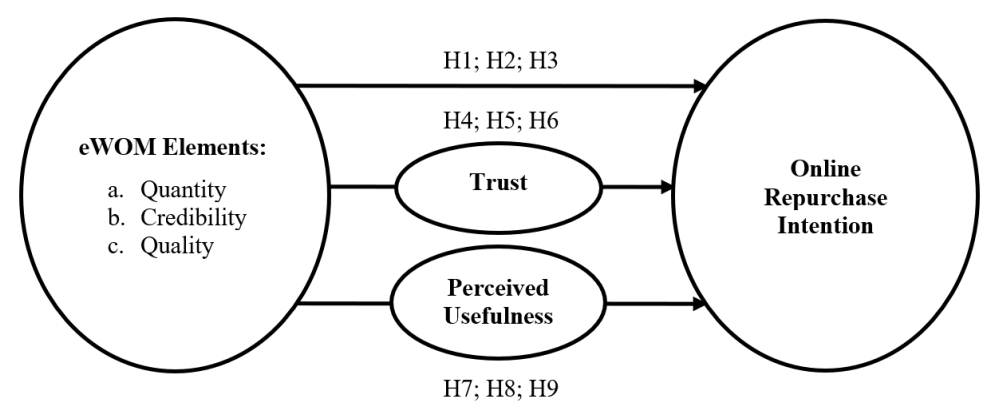

Figure 1: Research Framework

Source: Matute et al. (2016: 1098) 


\section{Methodology}

To measure the research data, PLS-based SEM was applied. The parameters were estimated using SmartPLS 3.2.7. SEM-PLS is considered to be a robust analytical method because it can be applied to all data scales and does not require strict assumptions (Ghozali \& Latan, 2015). The variables were assessed using items modified from earlier studies; a five-point Likert-type scale is applied to estimate variables $(1=$ completely disagrees; $5=$ fully agree $)$.

\subsection{Sample and Data Collection}

The online surveys (Google Forms) were used to obtain data from the respondents. The purposive sampling method was used as a sampling technique in this study. The non-random sampling technique is applied to determine requirements and special considerations when selecting sample units. The respondents' criteria were university students in Yogyakarta who had previously read online reviews before making an online purchase at Bukalapak. University students were chosen because most e-commerce users were dominated by young people aged between 20-30 (Kompas.com, 2018).

The minimum sample size is defined as a requirement for determining the SEM method's sample size (n). Jannoo et al.'s (2014) suggests that the recommended minimum sample size for this method range from 150 to 200 samples. This amount is the minimum criterion required in the process of estimating data using SEM. The sample size will show that the processed SEM data can consistently test the path coefficient's significance (Jannoo et al., 2014). 204 respondents were used for analysis in this study. The profile of the respondents is shown in Table 1.

Table 1: Respondent profile ( $\mathrm{n}=\mathbf{2 0 4})$

\begin{tabular}{lccc}
\hline \hline Variable & Category & Frequency & Percentage \\
\hline Age & $18-21$ & 88 & 43.1 \\
& $22-25$ & 116 & 56.9 \\
\hline Gender & Female & 72 & 35.3 \\
& Male & 132 & 64.7 \\
\hline Average monthly income (Rupiah) & $<$ Rp1.000.000 & 36 & 17.6 \\
& Rp1.000.001-Rp1.500.000 & 67 & 32.8 \\
& Rp1.500.001-Rp2.000.000 & 55 & 27.0 \\
& Rp2.000.001-Rp2.500.000 & 19 & 9.3 \\
& $>$ Rp2.500.001 & 27 & 13.2 \\
\hline Online shopping frequency in the last & $1-3$ & 159 & 77.9 \\
three months & $4-6$ & 40 & 19.6 \\
& $7-9$ & 5 & 2.5 \\
\hline
\end{tabular}




\subsection{Measurement Model}

In the PLS data analysis, the parameters will be estimated using the least square method. This estimation process will be carried out through iteration (repetition); the iteration will stop when the data has reached a convergent condition (Ghozali \& Latan, 2015).

The correlation between indicator values and construct values can be seen in a convergent validity test. According to Ghozali \& Latan (2015: 76), the rule of thumb usually applied to estimate convergent validity is the loading factor whose value must range between $>0.70$ and $>0.60$ to be accepted. The indicator value in outer loading must be more than 0.7, and the Average Variance Extracted (AVE) value must be more than 0.5 to be considered valid (Table 2 ).

Following the works of Ghozali \& Latan (2015: 75), we use the reliability test to prove the accuracy and the consistency of the instruments in measuring the research construct. The values of Composite Reliability (CR) and Cronbach's Alpha will determine the reliability of the construct. A research model will be considered reliable if it meets the following condition: Cronbach's Alpha values must be above 0.6 and Composite Reliability values above 0.7 (Table 2).

In the end, the final step will measure the discriminant validity of the construct by checking the value of square root AVE for each construct, which must be larger than the correlation shared with other constructs within the structural model (Table 3).

\section{Result and Discussion}

This study uses SmartPLS 3.2.7 as an analytical tool to test the structural model. The structural model consists of constructs (variables) with arrows in the dependent variable's direction (Figure 2). The process of making path diagrams based on the nomogram reticular action modeling (RAM) procedure. There are three independent variables; eWOM quantity, eWOM credibility, and eWOM quality, with two mediating variables; trust and perceived usefulness, and one dependent variable; online repurchase intention.

According to Ghozali \& Latan (2015: 80) this study will use the rule of thumb evaluation of structural models with a confidence level of $95 \%$ (alpha $=5 \%$ ) and $90 \%$ (alpha $=10 \%)$, and will compare t-statistics with t-tables (t-table for $5 \%=$ 1.96 and $t$-table for $10 \%=1.65)$ where $t$-stat $>1.65($ alpha $=10 \%)$ and $t$-stat $>1.96$ (alpha $=5 \%$ ) and compare p-values with a significance level of $5 \%$ with p-values $<0.05$ and a significance level of $10 \%$ with p-values $<0.1$ (Table 5 and 6).

The R-square results show that the model explains the 50,3\% variance for online repurchase intention, the $28 \%$ variance for perceived usefulness, and the $43.3 \%$ variance for trust (Table 4 ).

The path coefficient analysis on Hypothesis 1 indicates that eWOM quantity exerts negative influence on customer's online repurchase intention with a coefficient of -0.171 . T-statistic results $(2.846>1.960)$ and $P$-value $(0.005<0.05)$ indicate that $\mathrm{H} 1$ does not meet the criteria because the effect is negative, then 
Table 2: Convergent Validity and Reliability Values

\begin{tabular}{|c|c|c|c|c|c|}
\hline Construct & Item & Load $(\lambda)$ & AVE & Cronbach's $\alpha$ & CR \\
\hline \multirow[t]{3}{*}{ eWOM Quantity } & EQUAN1 & 0.837 & 0.705 & 0.790 & 0.878 \\
\hline & EQUAN2 & 0.783 & & & \\
\hline & EQUUAN3 & 0.896 & & & \\
\hline \multirow[t]{3}{*}{ eWOM Credibility } & ECRED1 & 0.843 & 0.732 & 0.817 & 0.891 \\
\hline & ECRED2 & 0.864 & & & \\
\hline & ECRED3 & 0.860 & & & \\
\hline \multirow[t]{9}{*}{ eWOM Quality } & TIM2 & 0.781 & 0.633 & 0.927 & 0.939 \\
\hline & TIM3 & 0.834 & & & \\
\hline & COMPR1 & 0.814 & & & \\
\hline & COMPR2 & 0.830 & & & \\
\hline & COMPR3 & 0.843 & & & \\
\hline & RELEV1 & 0.737 & & & \\
\hline & RELEV2 & 0.774 & & & \\
\hline & $\mathrm{ACC} 1$ & 0.819 & & & \\
\hline & ACC3 & 0.720 & & & \\
\hline \multirow[t]{7}{*}{ Trust } & HON1 & 0.770 & 0.591 & 0.884 & 0.910 \\
\hline & HON2 & 0.804 & & & \\
\hline & HON3 & 0.733 & & & \\
\hline & BENEV1 & 0.805 & & & \\
\hline & BENEV2 & 0.808 & & & \\
\hline & BENEV3 & 0.723 & & & \\
\hline & COMPET3 & 0.732 & & & \\
\hline \multirow[t]{4}{*}{ Perceived Usefulness } & PU1 & 0.727 & 0.593 & 0.771 & 0.853 \\
\hline & PU2 & 0.753 & & & \\
\hline & PU3 & 0.825 & & & \\
\hline & PU4 & 0.773 & & & \\
\hline \multirow[t]{3}{*}{ Online Repurchase Intention } & RI1 & 0.821 & 0.695 & 0.782 & 0.872 \\
\hline & RI2 & 0.862 & & & \\
\hline & RI3 & 0.817 & & & \\
\hline
\end{tabular}

Source: Output SmartPLS 3.2.7

Table 3: Discriminant Validity Values

\begin{tabular}{lcccccc}
\hline \hline & EQUAN & ECRED & EQUAL & TRUST & PU & RI \\
\hline EQUAN & $\mathbf{0 . 8 4 0}$ & & & & & \\
ECRED & 0.642 & $\mathbf{0 . 8 5 5}$ & & & & \\
EQUAL & 0.679 & 0.773 & $\mathbf{0 . 7 9 6}$ & & & \\
TRUST & 0.517 & 0.602 & 0.625 & $\mathbf{0 . 7 6 9}$ & & \\
PU & 0.440 & 0.444 & 0.513 & 0.620 & $\mathbf{0 . 7 7 0}$ & \\
RI & 0.373 & 0.556 & 0.572 & 0.604 & 0.585 & $\mathbf{0 . 8 3 4}$ \\
\hline
\end{tabular}

Source: Output SmartPLS 3.2.7

H1 is not accepted (Table 5). Although online reviews are considered to represent the popularity of goods and services, too much information will create confusion among customers, making them feel uneasy or even preventing them from processing information, so customers are under the negative impression when making the purchase. (Matute et al., 2016), thus exerting impact on their repurchase behaviour. With too much information, customers will spend too 


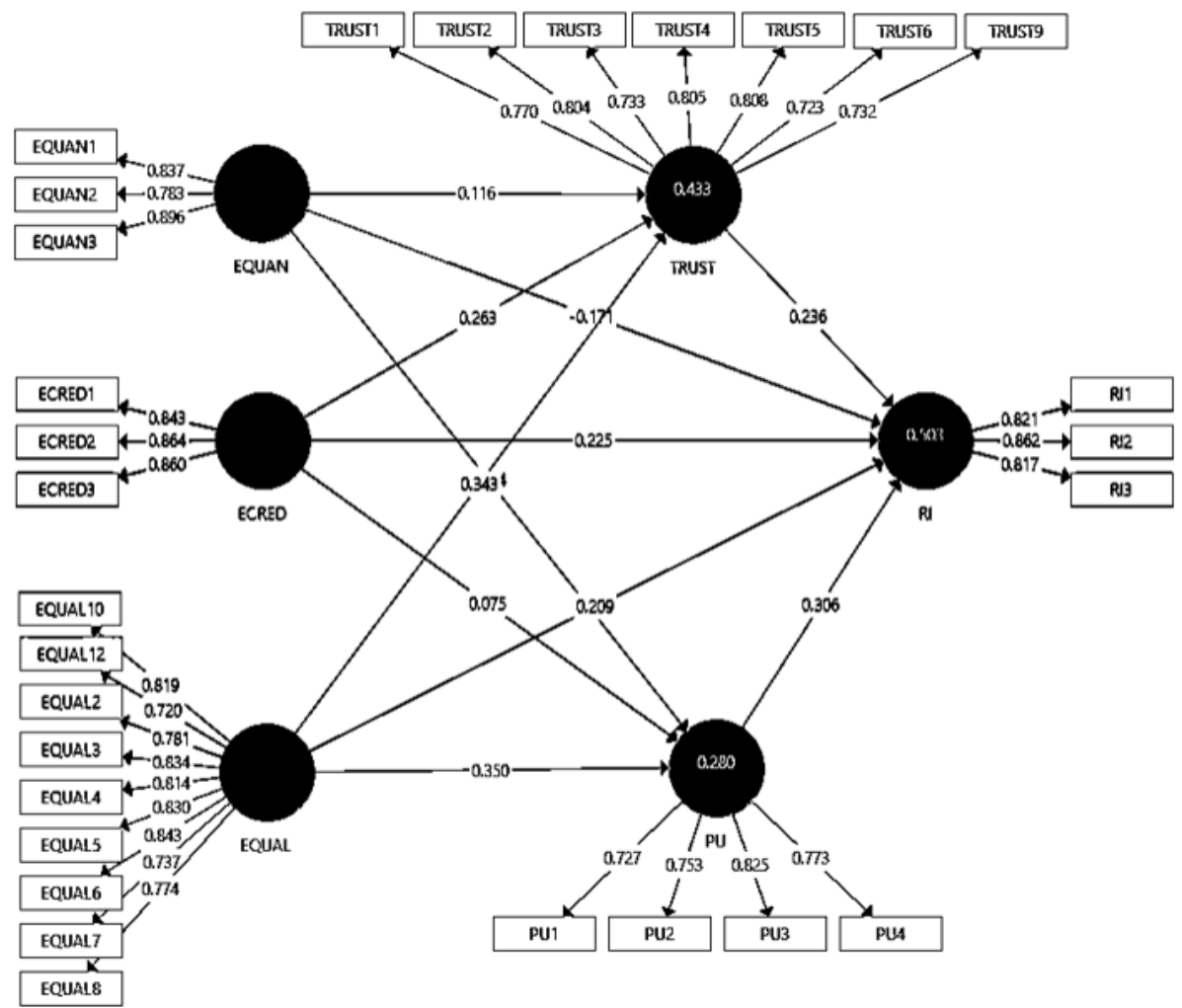

Figure 2: Structural Model Results

Source: Output SmartPLS 3.2.7

Table 4: Result of R-square

\begin{tabular}{lcc}
\hline \hline & R Square & R Square Adjusted \\
\hline Trust & 0.433 & 0.424 \\
Perceived Usefulness & 0.280 & 0.270 \\
Repurchase Intention & 0.503 & 0.491 \\
\hline
\end{tabular}

Source: Output SmartPLS 3.2.7

Table 5: Results of Direct Effects

\begin{tabular}{lcccc}
\hline \hline & Beta & T-statistics & P-values & Verification \\
\hline EQUAN $\rightarrow$ RI & -0.171 & $2.846^{*}$ & $0.005^{*}$ & Rejected \\
ECRED $\rightarrow$ RI & 0.225 & $2.310^{*}$ & $0.021^{*}$ & Supported \\
EQUAL $\rightarrow$ RI & 0.209 & $1.879^{* *}$ & $0.060^{* *}$ & Supported \\
\hline
\end{tabular}

Source: Output SmartPLS 3.2.7

Notes: $>1,96^{*}>1,65^{* *}$ Significant; $<0,05^{*}<0,1^{* *}$ Significant 
much time processing information, experiencing stress, and this will ultimately influence their decision-making process (Jackson \& Farzaneh, 2012).

The path coefficient analysis on Hypothesis 2 shows that eWOM credibility exerts positive influence on customer's online repurchase intention with a coefficient of 0.225 . T-statistic results $(2.310>1.960)$ and P-value $(0.021<0.05)$ indicate that H2 has met the criteria (Table 5). According to Filieri et al. (2019), online reviews will be useful for customers if the information provided is trustworthy. Customer's honesty in making recommendations will determine the decision to revisit a website (Park et al., 2011). However, if the customer's review displays biased information, the credibility level will decrease (Matute et al., 2016). In this study, customers have believed that online reviews they read have credible and relevant information. As such, customers will tend to revisit the website more often to make a repurchase.

The path coefficient analysis on Hypothesis 3 shows a positive association between eWOM quality and customer's online repurchase intention with a coefficient of 0.209 . T-statistic results $(1,879>1,650)$ and P-values $(0.060<0.1)$ indicate that $\mathrm{H} 3$ meets the criteria (Table 5). This result confirms the conjecture that higher quality of customer's messages exerts positive influence on their repurchase decisions. Consistent with prior studies, Chen \& Chen (2019) finds that the customer's intention to make a repeat purchase was affected by high-quality information, such as useful information and those that are deemed sufficient for meeting their needs. Customers will revisit the website to make future purchases because the website possesses quality, up-to-date, accurate, and relevant information (Matute et al., 2016).

Table 6: Results of Specific Indirect Effects

\begin{tabular}{lcccc}
\hline \hline & Beta & T-statistics & P-values & Verification \\
\hline EQUAN $\rightarrow$ TRUST $\rightarrow$ RI & 0.027 & 1.350 & 0.177 & Rejected \\
ECRED $\rightarrow$ TRUST $\rightarrow$ RI & 0.062 & $2.370^{*}$ & $0.018^{*}$ & Supported \\
EQUAL $\rightarrow$ TRUST $\rightarrow$ RI & 0.081 & $2.391^{*}$ & $0.017^{*}$ & Supported \\
EQUAN $\rightarrow$ PU $\rightarrow$ RI & 0.047 & 1.417 & 0.157 & Rejected \\
ECRED $\rightarrow$ PU $\rightarrow$ RI & 0.023 & 0.711 & 0.477 & Rejected \\
EQUAL $\rightarrow$ PU $\rightarrow$ RI & 0.107 & $2.363^{*}$ & $0.018^{*}$ & Supported \\
\hline
\end{tabular}

Source: Output SmartPLS 3.2.7

Notes: $>1,96^{*}>1,65^{* *}$ Significant; $<0,05^{*}<0,1^{* *}$ Significant

Hypothesis 4 states that the effect of eWOM quantity on customer's online repurchase intention has been mediated by trust. The results of the Specific Indirect Effects analysis show that T-statistic results $(1.350<1.650)$ and P-value $(0.177>0.1)$ indicate that $\mathrm{H} 4$ does not meet the criteria (Table 6). Based on the development of other mediation types by Zhao et al. (2010), trust in this hypothesis is considered a non-mediation category. Park et al. (2011) found that the higher the number of customers who post their online recommendations, the weaker the transaction risk. However, many online reviews do not change the level of customer's confidence toward sellers (Matute et al., 2016). In this context, the seller who relies 
solely on online reviews without providing optimal services such as excellent customer support or creative marketing content will not build the customer's confidence to do repurchase.

Hypothesis 5 states that the effect of eWOM credibility on customer's online repurchase intention has mediated by trust. The Specific Indirect Effects analysis result confirms that there is a positive influence with a coefficient of $0.027, \mathrm{~T}$ statistic results $(2.370>1.960)$, and P-value $(0.018<0.05)$ indicate that $\mathrm{H} 5$ meets the criteria (Table 6). Based on Zhao et al. (2010), trust in this hypothesis is considered complementary mediation. Coherently with previous research, Park et al. (2011) and Yeap et al. (2014) found that online reviews' credibility influences customers' confidence in making purchasing decisions. In this context, the online review has been seen as credible information (believable reviews) and increases customer's confidence towards the seller according to their needs. In the end, customers will "adopt" these online reviews to build positive trust and make repeat purchases.

Hypothesis 6 states that the effect of eWOM quality on customer's online repurchase intention has mediated by trust. The results of the Specific Indirect Effects analysis show that there is a positive influence with a coefficient of 0.081 , T-statistic results $(2.391>1.96)$, and P-value $(0.017<0.05)$ indicate that H6 has met the criteria (Table 6). Based on Zhao et al. (2010), trust in this hypothesis is considered complementary mediation. Matute et al. (2016) assume that an online review with up-to-date, consistent, and relevant information will act as the face of the online vendor's reputation. Customers will depend on reviews containing quality and trusted information. In this context, the availability of up-to-date, complete, relevant, and actual information has increased customer confidence and reduced customer's anxiety in making repeat purchases (Chen \& Chen, 2019).

Hypothesis 7 states that the effect of eWOM quantity on customer's online repurchase intention has been mediated by perceived usefulness. The Specific Indirect Effects analysis shows that T-statistic results $(1.417<1.65)$ and P-values $(0.157>0.1)$ indicate that H7 does not meet the criteria (Table 6). Based on the development of other mediation types by Zhao et al. (2010), perceived usefulness in this hypothesis can be considered non-mediation. In the previous study, Matute et al. (2016) found that many reviews can change customer usefulness perceptions to evaluate products. In this study, customers only view the website's usefulness as a tool to obtain large amounts of information. This action means that customers already feel the site's benefits, but it does not affect the customer's intention to repurchase (Yoo \& Ross, 2014). Consumers use the online store to shop and discover other products and services.

Hypothesis 8 states that the effect of eWOM credibility on customer's online repurchase intention has mediated by perceived usefulness. The Specific Indirect Effects analysis shows that T-statistic results $(0.711<1.65)$ and P-values $(0.477>0.1)$ indicate that $\mathrm{H} 8$ does not meet the criteria (Table 6). Based on the development of other mediation types by Zhao et al. (2010), perceived usefulness in this hypothesis is considered a non-mediation category. In this study, there is a possibility that 
the customers do not felt the usefulness of the website while obtaining credible information. Information may appear trustworthy but not useful and current but inaccurate (Matute et al., 2016). Customers still have to put more effort into getting those credible reviews. It leads to possibilities that customers prefer not to repurchase if they do not acknowledge its satisfactory performance to provide credible reviews such as verified reviewers.

Hypothesis 9 states that the effect of eWOM quality on customer's online repurchase intention has mediated by perceived usefulness. The Specific Indirect Effects analysis confirms that there is a positive influence with a coefficient of 0.107, T-statistic results $(2.363>1.96)$ and P-value $(0.018<0.05)$ indicate that H9 meets the criteria (Table 6), which is compatible with previous studies (Chen et al., 2016; Xu \& Yao, 2015; Zheng et al., 2013). Based on the development of mediation types by Zhao et al. (2010), perceived usefulness in this hypothesis is considered complementary mediation. This study revealed that customers have considered that the website is useful because it provides quality aspects such as accurate, relevant, up-to-date, and specific information (Matute et al., 2016). The online store's design to keep the quality of information a priority has improved the customer shopping experience and motivated customers to make a repurchase.

\section{Conclusion}

The number of e-commerce users in Indonesia has grown exponentially in the recent decade. Technological advancements have also enabled consumers to file their complaints and/or record their opinions on products sold by online vendors in a swift manner. These comments and/or feedbacks from consumers are especially important, as they help online vendors obtain feedbacks from consumers in virtual spaces and improve their services in the future. This paper aims to study the importance of such consumer feedbacks - our paper specifically evaluates three main eWOM elements (message quantity, credibility and quality) that consumers perceive of while reading online reviews to create purchase decisions.

In our study, the customers' responses are explained by identifying two separate viewpoints. First, this research identified trust (honesty, benevolence, and competence) as customers' perception toward the online vendor. Second, the website's perceived usefulness (usability, colors, or symbols) will be measured to understands customer repurchase behavior. The outcomes of this research confirm the positive direct effect of eWOM credibility and quality on customer's repurchase intention while the quantity has a direct negative influence. Trust in the online vendor successfully mediated the influence of eWOM credibility and quality on online repurchase intention. Meanwhile, the website's perceived usefulness only mediates the impact of eWOM quality on customer online repurchase intention. 


\subsection{Managerial Implications}

This study highlights the importance of providing optimal services to online consumers. It is also crucial that online sellers continually improve the quality of their services by observing the customer reviews and making customers feel comfortable surfing on the website to buy a product. Website and online vendors are required to be able to work together to make customers satisfied when shopping. They cannot downplay the role that online consumers' reviews have played in maintaining the continuity of their businesses.

First, sellers should not rely solely on a large number of reviews. The online vendor must provide excellent customer services, such as giving feedback to every comment, complaint, and customer's suggestion. Second, the results also show that consumers have not felt the benefit of the e-marketplace in verifying the reviewers. That result indicates that the e-marketplace should be aware of the quality of a virtual space facility, such as confirming the reviewers' verification. The virtual spaces must make it easier for customers to share their shopping experience. Finally, the website and online vendor can design marketing strategies or launch marketing campaigns to build their business's competitive advantage.

\subsection{Limitations and Further Research}

The limitation of this research is that researchers do not perform the backtranslation method on the questionnaire. That problem allows the occurrence of misinterpretation of respondents' answers.

From a methodological point of view, this research applied purposive sampling with limited size. The sample data were collected from university students (native internet users) in Yogyakarta, Indonesia. Further research recommended creating some research in other cities or expand the scope of research outside Indonesia. Future studies are also expected to examine the differences between generations of internet users because the research respondents were only limited to native internet users.

Indonesia has several alternative e-commerce markets that offer goods and services with relatively similar functions and prices. Hence, consumers will not rely solely on one of those several e-marketplace options. Further research is expected to analyze the effect of price on online repurchase intention in the e-commerce context.

In this modern era, consumers are more accustomed to receiving information in the form of reviews, videos, and photos to illustrate individual consumer judgments about a product or service. It will help consumers to get better knowledge about the experiences of other consumers. Therefore, further research is suggested to analyze the importance of visual eWOM on consumer online behavior. 


\section{References}

[1] Bataineh, A. Q. (2015). The impact of perceived e-WOM on purchase intention: The mediating role of corporate image. International Journal of Marketing Studies, 7(1), 126. doi: https://doi.org/10.5539/ijms.v7n1p126.

[2] Chen, H. F., \& Chen, S. H. (2019). How website quality, service quality, perceived risk and customer satisfaction affects repurchase intension? a case of Taobao online shopping. Proceedings of the 10th International Conference on E-Education, E-Business, E-Management and E-Learning (pp. 326-328). doi: https://doi.org/10.1145/3306500.3306571.

[3] Chen, J., Teng, L., Yu, Y., \& Yu, X. (2016). The effect of online information sources on purchase intentions between consumers with high and low susceptibility to informational influence. Journal of Business Research, 69(2), 467-475. doi: https://doi.org/10.1016/j.jbusres.2015.05.003.

[4] Chong, A. Y. L., Khong, K. W., Ma, T., McCabe, S., \& Wang, Y. (2018). Analyzing key influences of tourists' acceptance of online reviews in travel decisions. Internet Research, 28(3), 564-586. doi: https://doi.org/10.1108/IntR-05-2017-0212.

[5] Filieri, R., Raguseo, E., \& Vitari, C. (2019). What moderates the influence of extremely negative ratings? The role of review and reviewer characteristics. International Journal of Hospitality Management, 77, 333-341. doi: https:/ /doi.org/10.1016/j.ijhm.2018.07.013.

[6] Ghozali, I., \& Latan, H. (2015). Partial least squares konsep, teknik dan aplikasi menggunakan program smartpls 3.0 untuk penelitian empiris. Semarang: Badan Penerbit UNDIP.

[7] Hidayanto, A. N., Ovirza, M., Anggia, P., Budi, N. F. A., \& Phusavat, K. (2017). The roles of electronic word of mouth and information searching in the promotion of a new e-commerce strategy: A case of online group buying in Indonesia. Journal of Theoretical and Applied Electronic Commerce Research, 12(3), 69-85. doi: https://doi.org/10.4067/S0718-18762017000300006.

[8] Huang, A. H., Chen, K., Yen, D. C., \& Tran, T. P. (2015). A study of factors that contribute to online review helpfulness. Computers in Human Behavior, 48, 17-27. doi: https://doi.org/10.1016/j.chb.2015.01.010.

[9] IPrice Insights. (2018). Peta E-Commerce Indonesia. Accessed 3 December 2019. https: //iprice.co.id/insights/mapofecommerce/.

[10] Jackson, T. W., \& Farzaneh, P. (2012). Theory-based model of factors affecting information overload. International Journal of Information Management, 32(6), 523-532. doi: https://doi.org/10.1016/j.ijinfomgt.2012.04.006.

[11] Jannoo, Z., Yap, B., Auchoybur, N., \& Lazim, M. (2014). The effect of nonnormality on CB-SEM and PLS-SEM path estimates. World Academy of Science, Engineering and Technology, Open Science Index 86, International Journal of Mathematical and Computational Sciences, 8(2), 285-291. doi: https://doi.org/10.5281/zenodo.1090631.

[12] Kompas.com. (2018). 80 persen konsumen belanja online orang muda dan wanita. Accessed 3 December 2019. https://lifestyle.kompas.com/read/2018/03/22/ $155001820 / 80$-persen-konsumen-belanja-online-orang-muda-dan-wanita?page $=$ all.

[13] Matute, J., Polo-Redondo, Y., \& Utrillas, A. (2016). The influence of EWOM characteristics on online repurchase intention: Mediating roles of trust and perceived usefulness. Online Information Review, 40(7), 1090-1110. doi: https:/ / doi.org/10.1108/OIR- 
11-2015-0373.

[14] Park, C., Wang, Y., Yao, Y., \& Kang, Y. R. (2011). Factors influencing eWOM effects: Using experience, credibility, and susceptibility. International Journal of Social Science and Humanity, 1(1), 74-79. doi: 10.7763/IJSSH.2011.V1.13.

[15] Peng, L., Liao, Q., Wang, X., \& He, X. (2016). Factors affecting female user information adoption: an empirical investigation on fashion shopping guide websites. Electronic Commerce Research, 16(2), 145-169. doi: https:/ / doi.org/10.1007/s10660-016-9213-z.

[16] Teng, S., Khong, K. W., Goh, W. W., \& Chong, A. Y. L. (2014). Examining the antecedents of persuasive eWOM messages in social media. Online Information Review, 38(6), 746-768. doi: https://doi.org/10.1108/OIR-04-2014-0089.

[17] Tirto.id. (2016, 5 Desember). Berapa besar pengaruh ulasan online pembeli saat berbelanja online?. Accessed 3 December 2019. https://tirto.id/ berapa-besar-pengaruh-ulasan-pembeli-saat-berbelanja-online-b7Gm.

[18] Widowati, H. (2019). Indonesia jadi negara dengan pertumbuhan e-commerce tercepat di dunia. Databoks.katadata.co.id: Pusat Data Ekonomi dan Bisnis Indonesia. Accessed 3 December 2019. https:/ / databoks.katadata.co.id/datapublish/2019/04/ 25/indonesia-jadi-negara-dengan-pertumbuhan-e-commerce-tercepat-di-dunia.

[19] Xu, X., \& Yao, Z. (2015). Understanding the role of argument quality in the adoption of online reviews: an empirical study integrating value-based decision and needs theory. Online Information Review, 39(7), 885-902. doi: https:/ /doi.org/10.1108/OIR05-2015-0149.

[20] Yang, Y., Sun, X., \& Wang, J. (2019). The value of reputation in electronic marketplaces. Journal of Research in Interactive Marketing, 13(4), 578-601. doi: https://doi.org/10.1108/JRIM-11-2018-0151.

[21] Yeap, J. A., Ignatius, J., \& Ramayah, T. (2014). Determining consumers' most preferred eWOM platform for movie reviews: A fuzzy analytic hierarchy process approach. Computers in Human Behavior, 31, 250-258. doi: https://doi.org/10.1016/j.chb.2013.10.034.

[22] Yoo, J., \& Ross, S. D. (2014). Understanding online purchase intentions of licensed sports merchandise through integration of technology acceptance model and trust. The Journal of SPORT, 3(1), 30-62. doi: http:/ / dx.doi.org/10.21038/sprt.2014.0312.

[23] Zhao, X., Lynch Jr, J. G., \& Chen, Q. (2010). Reconsidering Baron and Kenny: Myths and truths about mediation analysis. Journal of Consumer Research, 37(2), 197-206. doi: https://doi.org/10.1086/651257.

[24] Zheng, Y., Zhao, K., \& Stylianou, A. (2013). The impacts of information quality and system quality on users' continuance intention in information-exchange virtual communities: An empirical investigation. Decision Support Systems, 56, 513-524. doi: https://doi.org/10.1016/j.dss.2012.11.008. 
this page intentionally left blank 